\title{
GREEN BUILDING CONCEPT, RATING SYSTEM AND ITS MANAGEMENT IN CONSTRUCTION PROJECTS IN INDIA
}

\author{
Ehtesham Ahmad ${ }^{1}$, Massom Reza ${ }^{2}$ \\ ${ }^{1}$ PG Student, Construction Technology \& Management, Al-Falah School of Engineering \& Technology, Al-Falah \\ University, Haryana, India \\ ${ }^{2}$ Civil Engineering Department, Al-Falah School of Engineering \& Technology, Al-Falah University, Haryana, \\ India
}

\begin{abstract}
As we are aware that there is enormous increase in basic facilities and development of construction field in india and it is very important sector because it creates employment on large scale and play a pivotal role in economic growth. Due to economic growth, India is witnessing increase percentage of $9.5 \%$ as estimated to world standard of 5\% in construction industry .Due to growth in Construction sector and urbanization of population in india, construction sector exerts a lot of environmental pressure and consumes natural resources such as soil, water, wood, stones, metals, glass etc during construction and consume energy. Due to this , there is a rise in green growth in india because it focuses on energy conservation, energy efficiency, integration of renewables, lesser consumption of water and sustainable waste management. It also aims better indoor environment for the occupants and low emissions of $\mathrm{CO} 2$ by using recycled material. The green building concept has been gaining importance in India due lesser amount of energy consumption, lesser consumption of water and better solution for waste management.It is well known that Nothing can be achieved without energy and to reduce and utilize maximum level of energy, there should be consideration of how to decrease energy consumption throughout the course of construction, renovation and opreration of building. Due to global warming and environmental issue such as rise in air,water and land pollution we are at the stage where green concept building is to be adopted at war level in construction industry. As we are aware that Buildings is , enormous consumer of energy and responsible for emission of green house gases, the concept of green building is the need of the Hour. Here it's a small concept presented in paper how building can meet environmental goals with minimum use of energy and the organization involve in the management and promotion of green building.
\end{abstract}

Keywords: - Sustainability, CO2, Ecosystem, Green Buildings, Renewable, Green Design

\section{INTRODUCTION}

Green buildings are adapted to climate and very efficient in terms of planning of earth resource and reducing environment influence throughout its operation. It is also recognized as high performance or green building. It creates positive impact on our climate and natural environment. It preserve natural resources and improve our quality of life. Green building Philosphy is based on the following principles:-

- Make efficient use of land preserving natural topography and vegetation.

- Efficient Use of Natural and manufacture Material through efficient planning.

- Efficient use of water, Preserve water through harvesting scheme and generate soft water though treatment plant to minimize use of potable water.

- Minimal Or no waste.

- Efficient use of energy both renewable and non renewable through different parameters and efficient planning.

- Last but not least, Provide healthy indoor environment for it occupant.
So basically a green or sustainable building focuses on an excellent use of natural resources, energy, maintain waste in efficient way and creates spaces for healthy and conformable living.

\section{NEED FOR GREEN BUILDING}

Due to enormous increase in basic facilities and development of construction field in India, the construction industry here is growing with the pace and prove to be biggest economic activities since it is increasing at the rate of $9.5 \%$ as estimated to world standard of $5 \%$. Due to enormous growth of construction industry in india it poses environmental threat. Due to this growth rate now it is mandatory under envioronment protection act 1986, all the construction activities involving the investment more than 50 crores must obtain the certificate and approval from EIA before starting the construction.

Building industry in India is the biggest contributors to direct and indirect Greenhouse Gas (GHG) emissions in the country. As per UNEP Report, buildings add 1/3 of total global greenhouse gas (GHG) emissions. The construction industry add upto $30 \%$ of world yearly GHG production and 
absorbs $40 \%$ of all energy . One of the main culprits is carbon dioxide emissions, which is implicated to contribute up to $40 \%$ of all global emissions in which India's position is 144th ranking in CO2 emission in the world. Due to carbon emission Kyoto protocol applies from February 2005 and it aims to reduce green house gas emission. It is environmental treaty followed by different industrial nation(39 nation) to reduce $\mathrm{CO} 2$ by different measure. The source of this protocol can be find back to 1997.

Due to increase in construction and environmental issue green building is the need of hour and have the following:-

- Environmental Gains: Green buildings have environmental benefits because it reduce the use of earth natural resources .maintain ecological balance, maintain and improve better quality of air and water and minimize waste.

- Economic Gains: Green buildings prove to be economical beneficial since in long running it reduces energy bill, operational bill ,rise in property value and improve the efficiency of manpower or its productivity due to healthy environment inside the green building enclosure.

- Health and Community Gains: Green buildings have improve indoor air quality, good ventilation system, thermal comfort, good visibility, daylight and due to this benefits it improve the health, comforts and improve all aspects of life of the occupants as well as the nearby community. The community gets benefits due the reduction in the uses of local infrastructure.

Last but not least it help reduce greenhouse gases.

The green concepts in the construction industry address the following issue which is also national concern:-

- Water Performance and reduction of potable water use by $40 \%$.

- Energy Performance, decreasing energy use by $30-5 \%$ from baseline.

- Reduction in Non renewable energy

- Reduction in waste by $70 \%$.

- Protect earth natural resources.

- Boost occupant health and productivity.

- $\quad$ Reduce $\mathrm{CO} 2$ emission by $35 \%$.

\subsection{Objective of Green Building}

The main aim of the sustainable green building construction is to examine the technique that minimizes environment impacts. It can be summarize as mention below:-

- Green building construction also help in establishing policy regarding green building for the region and also advance green building practices in the region by setting examples by utilizing energy, water, waste and material used in a building in a efficient way .

- Green building practices also set examples to reduce environment impact through innovative ideas and design adopted to decrease total impact on the surrounding and also on human fitness.
- To provide research to support green building construction.

- To influence and educate others to support the construction of green building in the region.

- Green buildings also minimize the available earth resources during construction and operational stage.

- Green or sustainable building construction emphasizes use of efficient waste management practices.

- Provide comfortable and hygienic indoor condition through ventilation and day light.

- Reduces carbon dioxide emissions.

\subsection{Advantage of Green or Sustainable Building}

Sustainable building have many advantages and governments also promote the green projects due to is benefits and also gives compensation for green projects. Green building projects have environmental, economis and social benefit.. Some of the benefits are illustrated below:-

- Green building promote habitat and biodiversity by minimizing disturbances and restoring the site..

- Green building promotes how to check and curb soil erosion and sedimentation responsible for decreasing adverse impact to site and surrounding.

- Green Building focus on the use of vehicle which uses renewable energy thereby decreasing the adverse effects, arising from fossils fuel depends automobile.

- Green Building promote to the use of public transport to have low impact on environment by minimizing the use of vehicle.

- Green building protects and promotes existing trees and plant new saplings to maintain ecology and biodiversity.

- It decreases Heat island effect to have negative low impact on micro climate.

- It control light pollution to increase view of night sky access and improve the nocturnal environment.

- Green Building enhance water table and cut potable water requirement through the efficient management of rain water harvesting scheme and also by using high efficient plumbing fixture to reduce water loss.

- Green building have efficient management of irrigation system to reduce water loss in irrigation.

- Green building have mandatory to have sewage or effluent treatment plant to generate treated water on site to decrease the use of potable water.

- It encourages eco friendly refrigerant thereby minimizing impact on ozone layer.

- Green building optimized energy consumption through thermally exterior wall assembly, efficient lighting design, VFD on cooling tower, heat recovery wheels, uses of high performance glass ,BEE rated equipment such as chiller,pumps,DG etc.Energy Saving is possible from $5 \%$ to $35 \%$ less from the baseline.

- It focuses on the generation of renewable source of energy to minimize the energy generated from fossils fuel and thus have low impact on environment. Reduces energy consumption up to 5 to $10 \%$. 
- In green building there is continous monitoring of energy consumption through meters to identify energy consumption of each zone which helps in improving the energy performance of building.

- Green building promotes dry or wet garbage segregation to promote reuse or recycle and thus avoiding all these waste generated is being deported to land fill.

- Green building promote ecofriendly building material ,reduce use of virgin material to avoid its negative impact on environment .Also it promote material with recycled contain such as RMC, steel, Glass, Cement etc

- Green Building provide effective measure to utilize organic waste.

- Green building provide good indoor environment quality by providing adequate outdoor air ventilation ,Monitoring CO2,Separate smoking zone area adequate daylight ,by using Low emitting materials such as paints ,adhesive and sealants, carpet etc.

\subsection{Conventional Building Vs Green Building}

By looking the building from outside, it is not possible to differentiate since green building and conventional building look same and have the same utility or the use.

The main difference between green building and conventional building is that green building have efficient planning and strategies to conserve the natural resources thus minimize impact on environment ,Minimizing energy consumption which result in cost saving in long run generate less waste and enhance health and productivity of occupant.
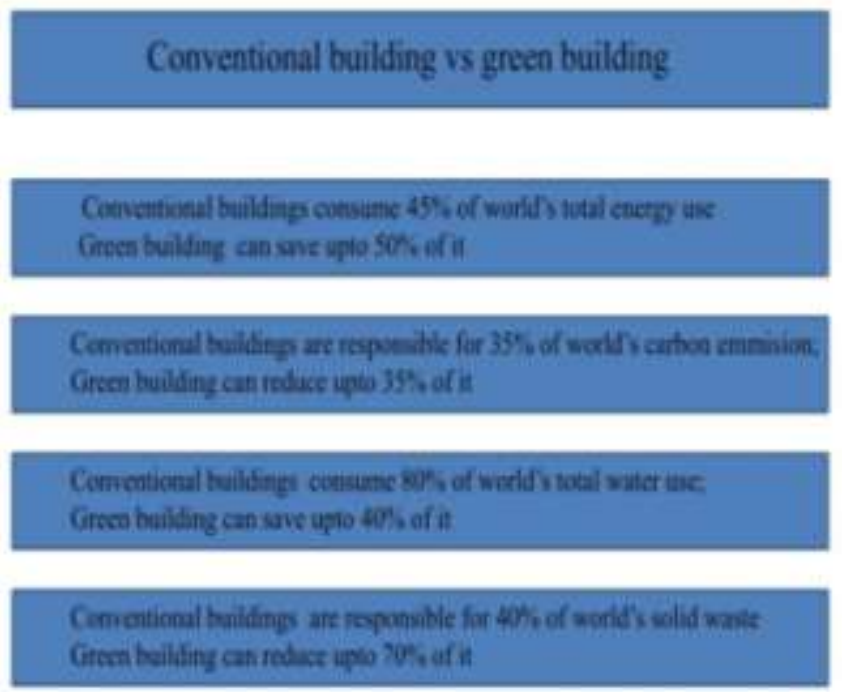

Source: State Environmental Resource Centre

Conventional buildings don't incorporate the efficient strategy to decrease the utilization of earth natural resources. So due to this conventional method of planning ,designing and execution of building leads to the maximum utilization of earth natural resources, high operational and maintenance cost and increase waste.

\section{GREEN BUILDING RATING SYSTEM}

Since building construction industry is growing tremendously in India, and construction is the second largest producer of demolition waste and green house gases(35\%$40 \%$ ), consume enormous amount of energy and generate large amount of solid and waste water. Due to this Rating system have been emerge as a means to evaluate building performance based on environmental consideration. Rating system are designed based on national background ,climatic condition and natural resource available. Rating system also standardize the practice. It helps the owner ,Architects, energy analyst, engineers ,building manager to achieve high performance building in a planned way from initial planning to final stage. Rating System is a powerful tool to measure green aspects in a building and can collectively make the difference.

There are different rating system available in different countries based on their national background such as:-

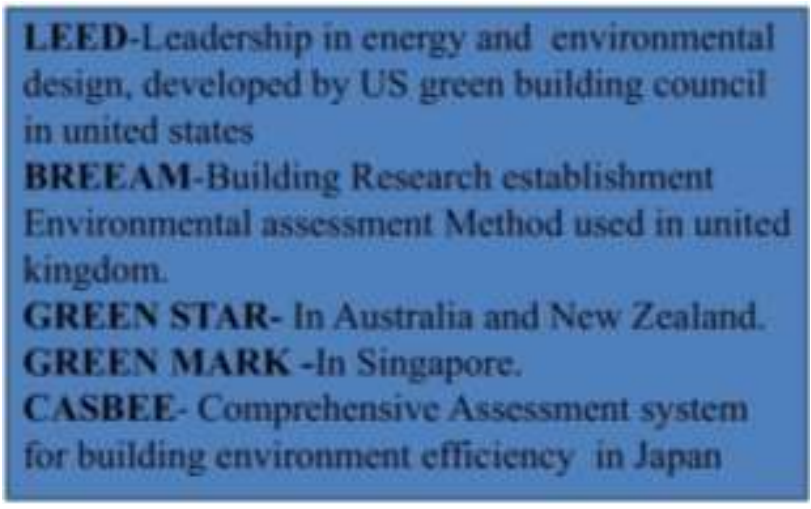

The green building development has led to the materialization of an assortment of green rating systems. The green rating systems that are currently being adopted in India are:

1) LEED India - maintain by the Indian Green Building Council (IGBC); formed by CII ( Confederation of Indian Industry) in 2001. CII - Godrej GBC, offers a services in following areas:-

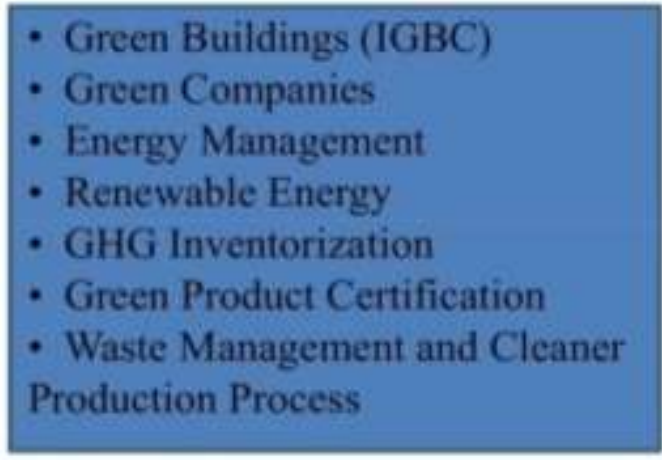

Source: IGBC 
2) GRIHA - Green Rating for Integrated Habitat Assessment developed by TERI (The Energy and Research Institute) and the Ministry of New and Renewable Energy, Government of India. It is a sustainable building design evaluation system where buildings are rated and consists of 34 criteria organized in different section.

3) BUREAU OF ENERGY EFFICIENCY(BEE) - BEE establish its own evaluating system for the buildings based on a 1 to 5 star scale.It is based on the actual consumption or performance of a building from baseline ,express in terms of its specific energy usage in $\mathrm{kwh} / \mathrm{sq}$ $\mathrm{m} /$ year. It rate building on a 1-5 Star scale, with building having 5 Star is being most efficient. More stars mean more energy efficiency.

\subsection{GRIHA - (Green Rating for Integrated Habitat}

\section{Assessment)}

Griha establish by TERI (The Energy and Resources Institute, New Delhi) in collaboration with MNRE (Ministry of New and Renewable Energy, Government of India) . the origination of word GRIHA is from a Sanskrit word meaning - 'Abode'. Human Habitats connect with the environment in different ways.

GRIHA was establish as an domestic building rating system based on climatic condition of india, which was particularly to focus on non air conditioned or partially air conditioned building .It is an establish organization to rate all types of building such as residential, commercial, institutional building etc in india and highlights environment concerns, local climatic condition and its domestic solution.

GRIHA focuses on better indoor environment by using passive solar technique for better visual and thermal comfort inside the building. It also promote the high consumption energy using air conditioned building only in extreme cases of thermal discomfort.

The GRIHA green rating tool mainly contain 34 different criteria divided under different group, such as site planning, construction management, energy, occupant comfort and well being, water, Sustainable building material, solid waste management, socio economic stragtegies and performance monitoring and validation. GRIHA incorporate all compatible Indian codes and buildings standard and acts as main mechanism to expedite operation of the same.
The point split of various section according to GRIHA
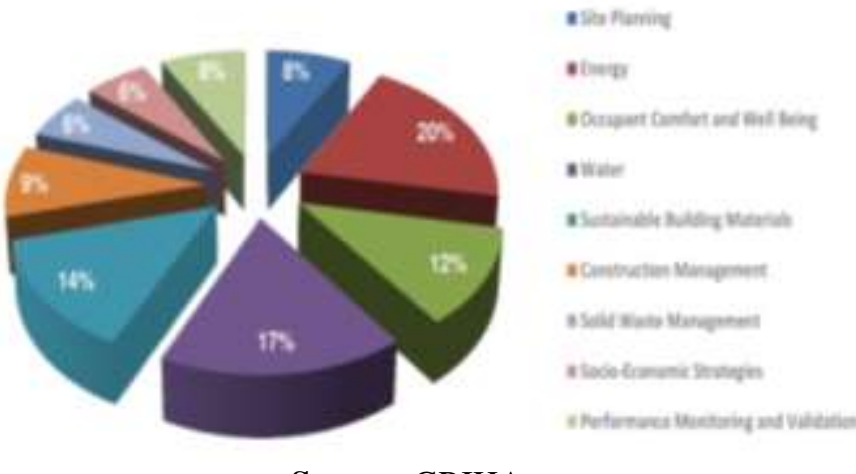

Source: GRIHA

Currently, 1125 projects are being evaluated by GRIHA and 78 buildings have been rated so far.GRIHA council also conducts awareness workshop on green building. As per data available from the year 2015 the GRIHA already spread to about $25 \mathrm{mn}$ Sqm registered built-up area which has resulted in a approximate generation of $18.5 \mathrm{MW}$ of renewable energy, $5000 \mathrm{kl}$ of hot water generation through solar. By operation of these building it is resulted of annual saving of energy 40,000 million units and water is approximate save which is enough for 67,500 urban homes.

The point split of various section according to GRIHA

\begin{tabular}{|c|c|c|c|}
\hline Sertins & $\begin{array}{l}\text { Craptiven } \\
\text { Ne. }\end{array}$ & Chenin Kie & $\begin{array}{l}\text { Mas } \\
\text { Puin }\end{array}$ \\
\hline \multirow[b]{4}{*}{ SIR MLANENG } & 1 & STE SELFCTON & 1 \\
\hline & 2 & LOW MPACT DESACY & 4 \\
\hline & 3 & DESICN TO MTMGATE LYIE & 2 \\
\hline & 4 & SIIE EELRVDOLSNESS FACTOR & 1 \\
\hline \multirow{3}{*}{$\begin{array}{l}\text { CONSTRUCTON } \\
\text { MANACEMSYY }\end{array}$} & 5 & 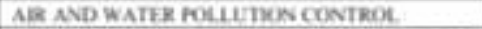 & 1 \\
\hline & 6 & 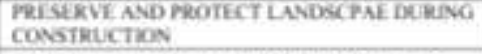 & 4 \\
\hline & $\pi$ & CONSTUUCTOON MANAGIMEST PLACTKCS & + \\
\hline \multirow[b]{3}{*}{ ENEWOY } & 1 & ENERGY EPECHANCY & 13 \\
\hline & 9 & RENEWABLF FEEROY UTHEATION & 7 \\
\hline & 10 & ZFRO ODP MATIKIAIS & ie \\
\hline \multirow{3}{*}{$\begin{array}{l}\text { OCCUPANT } \\
\text { CoMPONT AND } \\
\text { WELI BRINO }\end{array}$} & 11 & 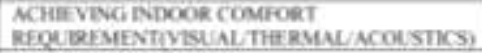 & 6 \\
\hline & 12 & MAISTANEVCOOOOLLO & 4 \\
\hline & 13 & 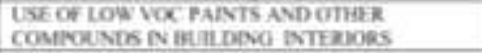 & 2 \\
\hline \multirow[b]{5}{*}{ WATE } & 14 & USE OF LOW RLOW IIXTIXES AND SYSTESE & 4 \\
\hline & is & RFDUCNG LANDSCAPE WATFR DEMAND & 4 \\
\hline & Is & WAIR QCALITY & $z$ \\
\hline & 17 & OK-SITE WATHR MFUSE & 5 \\
\hline & 18 & RADWATFE MFCHABOF & 2 \\
\hline \multirow{3}{*}{ 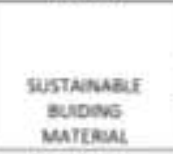 } & 19 & 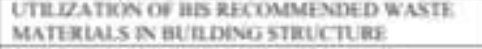 & 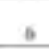 \\
\hline & $>0$ & 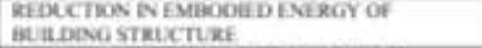 & 4 \\
\hline & 21 & 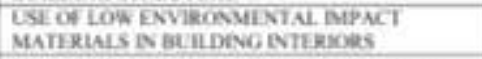 & 4 \\
\hline \multirow{2}{*}{$\begin{array}{l}\text { SQUD WNGT } \\
\text { MANGEUENT }\end{array}$} & 22 & 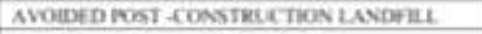 & 4 \\
\hline & 23 & TREAT OELCANK WASTE CN SIIF & 2 \\
\hline \multirow{4}{*}{$\begin{array}{l}\text { Socio econonac } \\
\text { STrearegis }\end{array}$} & 24 & LABOUX SAFETY ANDSASTITTIOV & 1 \\
\hline & 25 & DESIO Y FOR UNNERSAL ACCESSLEITYY & 2 \\
\hline & 3 & 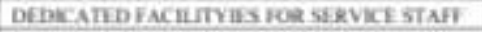 & 2 \\
\hline & 27 & 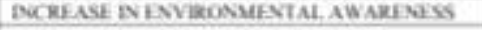 & 1 \\
\hline \multirow{5}{*}{ 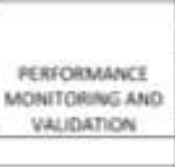 } & 25 & 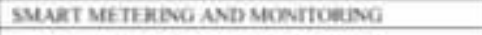 & 8 \\
\hline & $\mathbf{2}$ & OFRATMON MANTFAVCF PEOTOCOES & 0 \\
\hline & 30 & $\begin{array}{l}\text { FiRHOEMACE ASASSMENT FOR FINAL. } \\
\text { RATNG }\end{array}$ & i \\
\hline & 31 & INNOWATION & 4 \\
\hline & & TOTAL & 100 \\
\hline
\end{tabular}

Source: GRIHA 


\subsection{LEED India}

It is consensus based green building rating system which is based on the use of existing building technology. The Indian green building council(IGBC) has modified the US LEED system as per indigenous climate condition and situation of india and launch various version for old and new construction building.The green rating System focuses on impact of building on environment and enhance the energy efficiency of building and have good indoor environment .

1. Sustainable Sites (SS) :- The Sustainable Sites(SS) category is basically interaction between the building and environment surrounding. Credit in this category is based on the following points:-

- Site Preservation by not disturbing existing areas, by providing habitat and maintaining ecological balance and restoring destructive areas.

- Measure to curb soil erosion, to reduce environment impact.

- Reduce heat island effect

- Reduce light pollution to enhance nocturnal environment.

- Site should be located nearby to basic amenities such as banks, community centre, Fire station etc.

- Site should be nearby to public transport system to reduce pollution from automobile.

- Adequate parking facility within site.

- User friendly for differently abled person.

2. Water Efficiency(WE):- The Water Efficiency category focuses on water saving by analyzing overall consumption and how to minimize the overall consumption. Credit in this category is based on the following points:-

- Emphasize on the effective measure and management of rain water harvesting scheme to minimize the use of ground water and also to increase water table.

- Decrease utilization of potable water by treating sewerage waste water within the site and this water is further used in cooling system, flushing, washing and irrigation system.

- By limiting the installation of landscape which consumes large quantity of water.

- By efficient irrigation system.

- $\quad$ By using high efficient plumbing fixture.

3. Energy and Atmosphere(EA) :- The category of Energy and Atmosphere (EA) focuses on the reduction in the use of energy, efficient energy design consideration, and maximum use of renewable source of energy.

Credit in this category is based on the following points:-

- It aims to create high energy efficient building which uses less energy from base standard and through this approach it also reduces its environment impacts. It can be achieve through by considering building orientation, natural ventilation, appropriate building material, passive heating and cooling sytem, $U$ value of wall and roof, efficient planning for lighting power density, solar heat gain through glazing and window, and chiller efficiency.

- On site renewable energy at least $5 \%$ of total load and it is important that renewable source of energy makes less dependent on fossils fuels and also reduce the strain on electric grid during peak hour by generating electricity through solar panel or renewable source.

- By installing energy monitoring system.

- HCFC free air conditioning system.

- Encourage investment on offsite source of renewable energy.

- $\quad$ By using all BEE rated equipment.

4. Materials and Resources(MR):- This credit category focuses on the maximum use of recycled material or recycled contain material and less use of virgin material to minimize the environment impacts related to the extraction, transit, maintenance, process of manufacturing and dumping of building material.

Credit in this category is based on the following points:-

- It emphasize on division of waste originated at the source (Post occupancy) so as to avoid such waste being sent to landfill.

- It emphasizes to reduce construction waste being sent to landfill during construction and emphasize the recycling or reuse of the same material.

- More emphasis on such type of material or product having recycled contains.

- Emphasize to use locally available material, there by minimizing the add on environment impact.

- Emphasize the use of such material having low VOC content such as paints, carpet, adhesive and sealants etc.

- Encourage the use of green material which are easily renewable materials, having more salvaged content, and FSC certified wood product material.

- The use of certified green, products equipment or BEE rated.

5. Indoor Environmental Quality (EQ) :- This category deals with indoor environment and thermal comfort, visual, and acoustic satisfaction. Credit in this category is based on the following points:-

- Minimum fresh air ventilation for all occupied areas and in case of air conditioning building it has to meet standard prescribe in ASHRAE for minimum fresh air ventilation.

- Separate zone for smoking areas.

- Continuous monitoring of $\mathrm{CO} 2$ to ensure occupant comfort and well being.

- Adequate day light provision in building

- Ensure connectivity between indoor and outdoor environment by providing adequate views.

- Encourage use materials and system with low VOC emission so as to reduce adverse heath impact on building occupants. 
6. Innovation and Design Process :-. The aim of this category to go beyond the baseline set by IGBC to achieve more credit for the project. It also helps in Research and Analysis of green projects. It urge the professional associated in green projects to adopt new ideas which will result in better performance of green building. This category is purely based on innovation design ideas. Credit in this category is based on the following points:-

- It mainly consist of the areas of exemplary performance such as heat island reduction, natural topography or vegetation on site, water conservation, Building material and resources and outdoor views more than $95 \%$.

- It also aims to optimize structure design to have less consumption of cement and steel without compromising standards.

- Involvement of IGBC accredited Professional in green building projects.

These are the different category of IGBC Rating system available in India which are applicable to all climatic zone. IGBC work continuously in the field of green building rating system and incorporated all the modern concept related to this. Rating system is based on the classification of building. These are the following rating category classification of IGBC rating system:

\begin{tabular}{|c|c|c|c|c|}
\hline KAC RATING CATECORY & CERTIFIED & SIIVER & COLD & PLATINUM \\
\hline KaC Ginan Nex Buildisg & $40-49$ & 58.9 & (6)-74 & 75.100 \\
\hline GAC Gran R̂tsdattial Socitios & 30.39 & atis & $50-64$ & 65 A ABONE \\
\hline (XaC Giten SchwolsEXISTING) & 50.59 & (6) -49 & 72.79 & [0]-100 \\
\hline CAC Grem Scbods NEW SCHOOC, & 5566 & $86-76$ & $7.8 \%$ & 8.110 \\
\hline KaC Gran Cimpus EXISTING) & $40-49$ & $50-59$ & 60.74 & 75.84 \\
\hline KaAC Ginm CampusNEW) & 36.4 & $45 \cdot 53$ & 54.66 & 67.90 \\
\hline Kac Gram Citio & $\mathrm{NA}$ & $\mathrm{NA}$ & NA & $\mathrm{NA}$ \\
\hline XaC Gron Mass Rapid Tratsi Sygtent & $\mathrm{MA}$ & NA & $\mathrm{NA}$ & $\mathrm{Na}$ \\
\hline KäC Ginat Affindable Howiog & 38.4 & $45-51$ & $52 \cdot 59$ & $80 \cdot 65$ \\
\hline KaC Gran Exigine Builings & 50 +59 & $60-99$ & 10.79 & $80-100$ \\
\hline CaBC Ginut litinces & 30.4 & 45.54 & $55 \cdot 69$ & $70 \cdot 100$ \\
\hline XAC Gimen Futtor Buidity & $51 \cdot 60$ & $61-\pi 0$ & $71 \cdot 30$ & 84.160 \\
\hline Xac Giron Village & 40.49 & $50 \cdot 59$ & $60 \cdot \pi$ & $80 \cdot 100$ \\
\hline KäC Ginat 5573 & $51+60$ & $6 \mathrm{t}-7 \pi$ & $77 \cdot 80$ & $81-100$ \\
\hline KaGC Giran Exiving Kas Rapad Tnssit Systan & $\mathrm{MA}$ & $\mathrm{NA}$ & $\mathrm{NA}$ & $\mathrm{MA}$ \\
\hline KaC Healith und Wall-tengy Ratisy & $50-59$ & $60+60$ & N1). 79 & $80-100$ \\
\hline KaAC Gram Hotes INDIVIDCAL INT) & $38 \cdot 4$ & $45 \cdot 51$ & 52.39 & $60 \cdot 75$ \\
\hline KaC Gran Hones MULTI-DWELLCNG UNT) & $50 \cdot 59$ & $\theta+\theta$ & $10 \cdot 79$ & 10.89 \\
\hline KaC Ginat Helithare & $\mathrm{MA}$ & NA & NA & $\mathrm{MA}$ \\
\hline 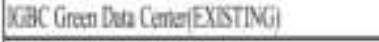 & 40.49 & $53-64$ & 65.79 & ; \\
\hline KaC Gron Dhin (eniel NEW) & 4049 & 30.64 & 65.99 & 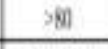 \\
\hline XaC Gresn Tenships & 100.119 & $130 \cdot 139$ & $140 \cdot 193$ & $|(\theta)-24|$ \\
\hline IGEC Geren LandsripusSMALL) & $45 \cdot 57$ & $54 \cdot 62$ & $63 \cdot \pi$ & $80+75$ \\
\hline IGBC Ginen Landsces: LARCE 25 . NGRE) & $50-29$ & $68-69$ & 70.79 & 72.96 \\
\hline
\end{tabular}

Source: IGBC
Rating systems of IGBC are based on the score achieve by the projects under key component describe above and according building is awarded as whether it is certified, silver, gold and platinum.. IGBC Rating system is suitable for all the climatic zone of country.

\section{GREEN GROWTH RATE IN INDIA}

The Green Building industry is growing in India due to environmental regulation and arising demand .Green building programme specially LEED transforming the green concept movement across the globe and LEED is recognized and widely used and most popular among the green rating system in the word. In India green building movement is lead by CII-Sohrabji Godrej Green Business and it was awarded as first platinum green rated building located in Hyderabad in India. The concept of green building is growing in India due to increase awareness level ,environmental benefits and government supports and it is estimated that green building will double by 2022 at 10 billion sqft valuing around USD 35-

Growth of green building over the year (Source-IGBC) 40 billion. As per data available from Indian Green Building Council there were 20,000 sqft of green built-up area in 2003 and as of now today more than 4,573 green building projects coming up with foot print of over 5.30 billion sqft registered with IGBC out of which 1384 are functional building based on green concept.

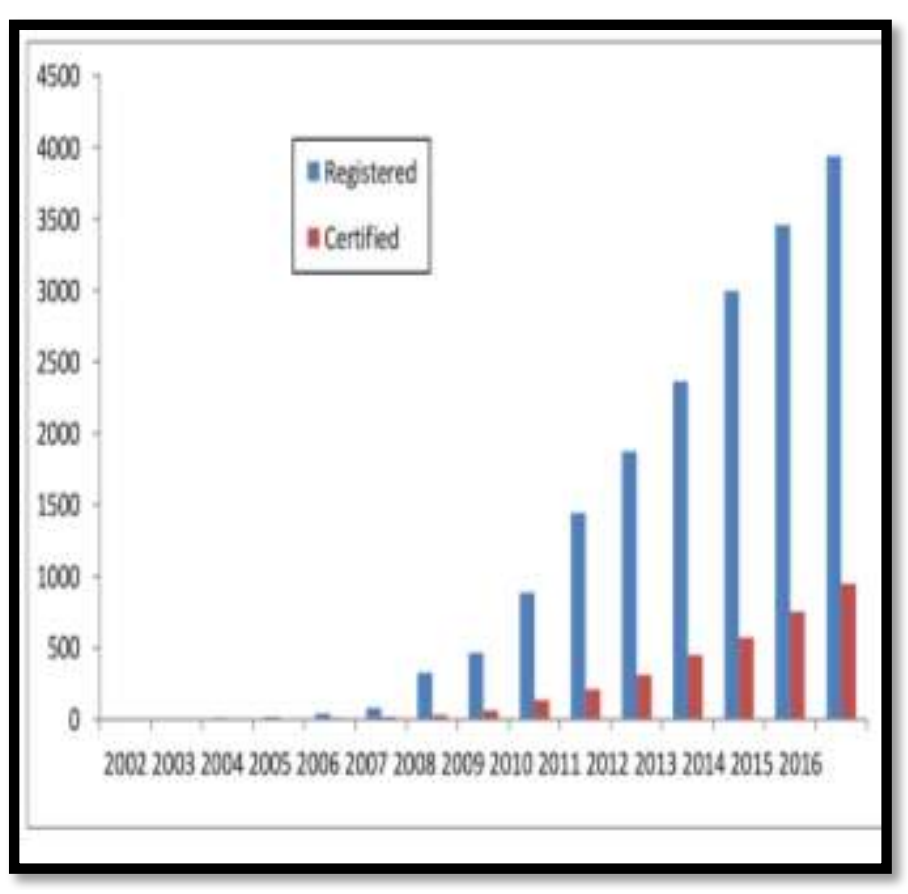

Source: IGBC 


\section{CASE STUDY}

\begin{tabular}{|c|c|c|c|}
\hline Achieved & Denicd & & \\
\hline $\mathbf{Y}$ & & Eresten \& Sedimentation Centrol & Prerequisite 1 - Ver 1.0 \\
\hline 1 & & Site Sleletion & Credit 1-Ver 1.0 \\
\hline 1 & & Development Density \& Community Connectivity & Credit 2-Ver 1.0 \\
\hline 1 & & Alternative Trancportatien, Public Tramsportation Access & Credit $4.1-V e r 1.0$ \\
\hline 1 & & Alternative Trassportation, Law Emisaion \& Alterautive Fael Refueling Stations & Credit $4.2-\operatorname{Ver} 1.0$ \\
\hline 1 & & Alternative Transpertatien, Parking Capacity & Credit $4.3-$ Ver 1.0 \\
\hline \multicolumn{2}{|c|}{ NOT ATILMPTID } & Starmwater Design, Quantity Control & Credit 6.1 - Ver 1.0 \\
\hline$i$ & & Sterm water Desige, Quality Centrol & Credit 6.2 -Ver 1.0 \\
\hline 1 & & Heat Istand Effect, Non - Reof & Credit $7.1-\operatorname{Ver} 1.0$ \\
\hline \multirow{2}{*}{\multicolumn{2}{|c|}{\begin{tabular}{|l|} 
NOT ATITMPTID \\
NOS
\end{tabular}}} & Heat Letand Effect, Roef & Credit $7.2-\operatorname{Ver} 1.0$ \\
\hline & & Tight Pollution Reductien & Credit $\mathrm{B}$ - Ver 1.0 \\
\hline \multicolumn{2}{|c|}{ NOT ATITEPTID } & Tenant Desige and Constructien Cinidetines & Credit $9-$ Ver 1.0 \\
\hline 1 & & Innovative Wastewater Technologies & Credit 3 -Ver 1.0 \\
\hline 1 & & Water Use Redection, $20 \%$ Redectien & Credit $4.1-\operatorname{Ver} 1.0$ \\
\hline 1 & & Water Use Reduction, $30 \%$, Redection & Credit $4.2-\operatorname{Ver} 1.0$ \\
\hline Achieved & Denied & & \\
\hline 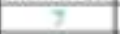 & 1 & Feergy \& Atmesphere. & Pessible Peints - 17 \\
\hline $\bar{Y}$ & & Fundamental Buildiag Systems Cammissianing & Prereyuisite 1 - Ver 1.0 \\
\hline $\mathrm{Y}$ & & Minimum Energy Performance & Prernquisite 2 - Ver 1.0 \\
\hline $\mathrm{Y}$ & & CFC Reduction in IVVACA R Equipment & Prerequisite 3 - Ver 1.0 \\
\hline 4 & & Optimize Enerny Performance & Credil I - Ver 1.0 \\
\hline NOT ATI & IMMTID & Renewable Iacrgy, $1 \%$ & Credit $2-$ Ver 1.0 \\
\hline & 1 & Adsitional Commissioning & Credit 3 - Ver 1.0 \\
\hline 1 & & Orane Depletion & Credit 4-Ver 1.0 \\
\hline i & & Measurcment \& Verification - Hase Building & Credit $5.1-$ Ver 1.0 \\
\hline 1 & & Censtructien Waste Managemest, Divert 50\%, frem Dispesal & Credit 2.1-Ver 1.0 \\
\hline 1 & & Construction Waste Masagement, Divert 75\%, from Disposal & Crevitit 2.2-Ver 1.0 \\
\hline NMT AT & HMMTID & Resesurce Hesse, $1 \% 6$ & Credil $3.0-\operatorname{Ver} 1.0$ \\
\hline 1 & & Recycled Coetent, $5 \%$ (post -consumer + Y post -iedustrial) & Credit 4.1 - Ver 1.0 \\
\hline$\frac{1}{1}$ & & Recycted Centemt, $10 \%$ (pest-consumer +3 post -industriah) & Credit $4.2-$ Ver 1.0 \\
\hline 1 & & Regienal Materiale, $20 \%$ Manufactured Regienally & Credit 5.1 - Ver 1.0 \\
\hline 1 & & Regienal Materiais, so"s. Evtracted Megienally & Credit $5.2-\operatorname{Ver} 1.0$ \\
\hline NOT AT & IMPTD & Certined Weod, sept of weed based materials & Credit $6-$ Ver 1.0 \\
\hline Achieved & Dentied & & \\
\hline 5 & 2 & Indeor 1 eviroumental Qualify & Pesulble Proints - 15 \\
\hline $\bar{Y}$ & & Minimum IAQ Performance & Prerequisite I - Ver 1.0 \\
\hline$Y$ & & Kavironmental Tebacce Smoke (ETS) Centrel & Prerequisite 2 - Ver 1.0 \\
\hline NOT ATH & IFMPTD & Outdear Air Detivery Menitering & Credit $1-$ Ver 1.0 \\
\hline 1 & & Increated Ventilation, $30 \%$ above ASIIR AK 62.1 requircments & Credit 2-Ver 1.0 \\
\hline 1 & & Construction 14Q Management Mlan, (During Cosstructien) & Credit 3 - Ver 1.8 \\
\hline 1 & & Low-Emittiag Materials, Aathesive $\&$ Sealants & Credil 4.1 - Ver 1.0 \\
\hline 0 & & Low Emitting Materialc, Paints & Crvalit 4.2 -Ver 1.40 \\
\hline 1 & & Low-Kmirting Materiak, Carpet & Credit $4.3-$ Ver 1.0 \\
\hline & 1 & Low Emitting Materials, Compesite Weod \& Agrifiber products & Credil 4.4-Ver 1.0 \\
\hline NOT ATI & IIMPTHD & Indeer Chemical \& Pellutant Seurce Centrol & Credit 5-Ver 1.0 \\
\hline NOT ATI & TEMPID & Contretlability of Systems, lighting & Credit $6.1-$ Ver 1.0 \\
\hline NOT ATI & IIMTIID & Controllability of Systems, Thermal Comfort & Credit $6.2-\operatorname{Ver} 1.0$ \\
\hline & 1 & Thermal Cemfort, Desigh & Credil 7.1 -Ver 1.0 \\
\hline NOT AT & INMFIID & Thermal Cemfort, Verification & Creelit $7.2-\operatorname{Ver} 1.0$ \\
\hline NOT $\mathrm{AT}$ & IFMPIID & Day light, Daylight 75\%6 of Spaces & Credit 8.1 - Ver 1.0 \\
\hline 1 & & Views, Views for $90 \% 6$ of Spaces & Credit $8.2-\operatorname{Ver} 1.0$ \\
\hline
\end{tabular}


To understand the concept of green building rating system ,a IT building situated in Gurugram's sohna road have been studied and all the related point awarded and denied is mention in a tabular form. This IT building is about 600,000 sqft and is located in 63 acre campus in gurugram. It is awarded as a gold certified building in 2013.In the construction phase of building importance was given to use eco friendly material and minimize the use of virgin wood. The building has different feature which enables to optimize energy consumption such as orientation, High performance glass, insulation of roof and wall, efficient HVAC system with efficient centrifugal chillers, variable frequency drive(VFD) and heat recovery system. The building has some additional features to conserve potable water by using grey water in irrigation of landscape, washing, fushing and cooling towers. The Building Score 35 point and achieve certification as a gold rated building and is fully functional under the category of "Core and Shell"by IGBC.

\section{COST ANALYSIS OF GREEN BUILDING}

It is point of discussion and research that a green building cost more. In india as per data available most green building there is increment cost of 2-12\% from baseline depending on rating category. Due to tremendous growth of construction industry in india and also due to environmental regulation such as EIA the distance between the conventional and green building is decreasing and green building cost is also decreasing due to mandatory points set by EIA(MOEF). Now it is becoming myth that green building cost more and now it is possible by analyzing the market the green material is also available in abundance due to increase in demand and green growth and benefits associated with it is that green material have lower impact on environment. It is also easy to minimize the cost of green building, if all the parameter are carefully studied and incorporated at the design stage only.

It should be keep in mind that that if green building cost a little more but it has benefit such as reduced electricity bill ,reduce water bill, reduce operating cost , better comfort and better health. Nowadays the payback for green building is hardly 1 to 2 years.

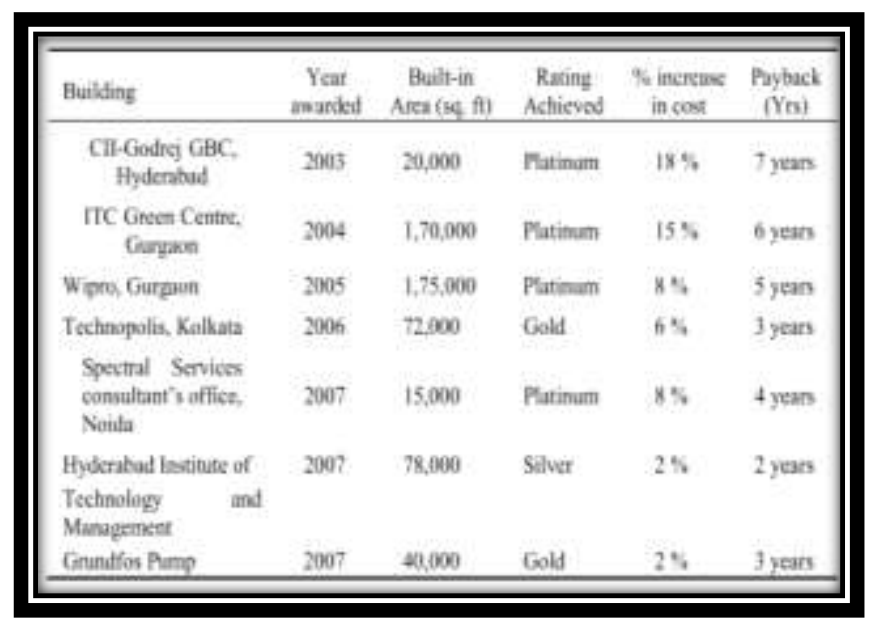

Source: CII
By analysis and research regarding cost in green building there are some parameter which increase the cost and some parameters decreases the cost. Some of the parameter which reduces the cost in the building by adopting green feature are as follows:-

- By adopting passive architecture design feature such as orientation, skylight, courtyard, shaded corridor, shading device, passive cooling and heating etc, it is possible to design building envelope in such a way that it will reduce dependency on air conditioning and artificial lighting and it will bring down initial construction cost as well as its operating cost.

- By selecting brown field because the land has lower market value.

- By easy access to basic amenities, and public transportation system and hence it will result in lower fuel consumption.

- By water conservation scheme through harvesting and use of treated water in cooling towers, landscape irrigation, car washing and flushing can reduce the use of potable water and hence reduce cost associated with them.

- Lower maintenance cost of equipment due to BEE rated equipment and green certified equipment.

- Due to minimize use of virgin material it can cut first cost of purchase.

- Due to use of salvage material in the building, material cost will reduce in green building.

- By optimization in structure design which will reduce the consumption of steel and cement. By using AAC block and fly ash in concrete ,the use of cement and steel can be minimize by $5 \%$ and it will result in reduce in cost.

Some of the parameter which increase the cost in the building by adopting green feature are as follows:-

- By adopting parameters to reduce heat island effect, it will increase the cost in green building.

- By using all BEE rated equipment it will put extra cost in green building in initial stage though have low maintenance cost in long term.

- By setting on site renewable source of energy, it will have major cost addition in initial stage though in long running it will be cost saving.

- Insulation of wall and roof will have cost addition in green building though it will reduce heat load on air conditioning system.

- Use of high performance glass as per green norms will have additional cost in initial stage.

- Use of certified wood and certified green equipment will cost more in green projects.

- High efficient plumbing fixture to reduce water consumption will have initial cost more in green building.

- $\quad \mathrm{CO} 2$ monitoring system to maintain occupant and well being will have additional cost in green building. 
- $\quad$ Building Management system (BMS) in green building will cost more due to maintenance and managing efficiency of building as per norms.

The overall cost analysis comparison cannot be justified unless all the parameters is studied and analysed. The overall cost comparison of green and conventional cannot be justified by cost increment or decrement method unless actual projects are studied and analysed.

\section{CONCLUSION}

Due to tremendous growth in construction industry and urbanization of population has resulted in maximum utilization of land and other earth natural resources which has put immense burden on the same. So the LEED /Green building can be regarded as game changer because green building is design in such a way that it can be reduce environment impact that are measurable. Also green building can reduce $\mathrm{CO} 2$ emission, water consumption and material use and also green building prove to be energy efficient building. Since India is developing country and have huge population, have impact on energy uses and energy uses is growing day by day .So it is very necessary since building consume a lot of energy. Government also promoting green concept and the use of energy based on renewable source. It's important to review financial aspect during planning and construction phase of a project to reduce development first cost in delivering green and sustainable building.

\section{FUTURE SCOPE}

Green building Technology is the only way the construction would be taken up in future due to enormous growth in construction sector and urbanization of population. It is very important in India since demand of energy consumption is more than supply and there is shortage of energy. In the coming future all construction in India should be green and low carbon. The green construction costing based on the life cycle is considerably low and it requires more professional knowledge. The future belongs to Green construction and professionals practicing it. A lot of people are becoming conscious of the concept of green buildings and profit associated with it and low impact on environment. In coming future green building will be more emphasize and promoted for better environment and society. The result coming out from the recently rated functional green building is very encouraging. It optimize energy consumption which result in reducing $\mathrm{CO} 2$ emmision. Now due to large foot print it is becoming cost effective. Day by day the green building concept is growing and implemented in construction worldwide.

\section{REFERENCES}

[1] GRIHA Manual Volume . Published by The Energy and Resources Institute Press, New Delhi, India.

[2] U.S. Green Building Council.

[3] IGBC
[4] "Buildings and Climate Change Report: Summary for Decisionmakers". United Nations Environment Programme, 2-11, 2009.

[5] "The Impacts of Construction and the Built Environment: briefing note", Willmott Dixon Group, Retrieved from http://www.willmottdixongroup.co.uk/assets/b/r/briefi ng-note33-impacts-of-construction-2.pdf, 2010.

[6] Comparison analysis of Green building materials and conventional materials in energy efficiency performance Srikant Misra, G.R.K.D. Satya Prasad, Navnit Kumar, Satish Kumar Sah, Sanjeet Kumar, Radheshyam Maurya International Research Journal of Engineering and Technology (IRJET) Volume: 03 Issue: 05 | May-2016.

[7] Designing Techniques of Green Buildings: Literature Review Shubra Gupta(Journal of Civil Engineering and Environmental Technology) Volume 2, Number 3; January-March, 2015.

[8] "GREEN BUILDING" Leader in Energy and environment Design for Building Sector. Jignesh C Sailor,Himanshu A Naik. Viral Kumar I Makwana.

[9] Cost Parameters of Green Residential Buildings in Pune, India. Anshul P Gujarathia(B.N. College of Architecture, Pune. Karvenagar, Pune, India ,ICIEA 2016)

\section{BIOGRAPHIES}

Ehtesham Ahmad, M.Tech, Construction Technology \&

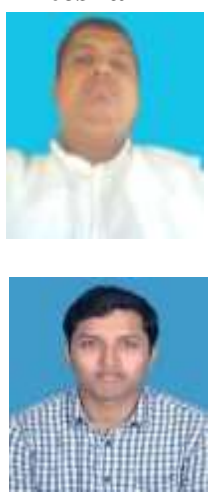
Mangement, Alflah University, Haryana, India, Email- ehteshamarch@gmail.com Mobile-9971353242.

Masoom Reza, Assistant Professor Civil Engineering Department Alflah University, Haryana, India 